\title{
Mixed Connective Tissue Disease Presenting Myasthenia Gravis
}

\author{
Masayuki Yasuda, Mawsheng Loo, Satoshi Shiokawa, Tetsuya WadA, \\ Yasuo SuEnaga and Masashi Nobunaga
}

\begin{abstract}
We herein describe a 41-year-old female patient with an association of myasthenia gravis (MG) with anti-acetylcholine receptor (AcR) antibody, mixed connective tissue disease (MCTD) and Sjögren's syndrome (SjS). We reviewed the reported association of MG and MCTD, systemic lupus erythematosus, progressive systemic sclerosis, polymyositis and dermatomyositis, and $\mathrm{SjS}$. Since we could find only two patients who fulfilled the diagnostic criteria for MCTD in the previous literature, we concluded that the association of MG and MCTD is rare. We also discuss the coexistence of $\mathrm{SjS}$ as one of the underlying pathological conditions for the association of MG and various connective tissue diseases including MCTD.

(Internal Medicine 32: 633-637, 1993)
\end{abstract}

Key words: Sjögren's syndrome, systemic lupus erythematosus, polyclonal B-cell activation

\section{Introduction}

Myasthenia gravis (MG) is an autoimmune disorder of the neuromuscular junction (1). The muscle weakness reflects the loss of functional acetylcholine receptor (AcR) at the postsynaptic membrane of the neuromuscular junction by autoantibody to AcR. It has been reported that patients with autoimmune disease often show an association of MG $(1,2)$. We treated a patient with $\mathrm{MG}$ and associated mixed connective tissue disease (MCTD) (3-5). Since we found that the association of MCTD and MG is rare, we present the clinical features of the patient and review previous case reports concerning the association of MG and various connective tissue diseases (CTD).

\section{Case Report}

In July 1992, a 41-year-old Japanese woman visited our institute hospital because of weakness and disorientation. She had experienced 3 instances of spontaneous abortion, Raynaud's phenomenon and photosensitivity over the previous 20 years. Subarachnoid bleeding due to the rupture of a cerebral aneurysm occurred in January 1988. She underwent a clipping operation and ventriculo-peritoneal shunt. In June 1991, she noticed disorientation and muscle weakness with gait disturbance.

She complained of a mild arthralgia without joint deformity as well as a mild dryness of the eyes and mouth. She had photosensitivity, sclerodactylia as well as swollen hands, Raynaud's phenomenon, and pigmentation in the lower extremities. No struma was observed. Her consciousness was that of a stupor and disorientation was also observed. The tendon reflexes and sensations were normal. Muscle weakness with ataxic gait and ptosis of the eyelids were observed, but neither muscle atrophy nor diplopia were found.

A CT of the brain disclosed a deformity of the skull due to the previous operation for subarachnoid bleeding and there were two areas of calcification around the left sylvian fissure. A decrease in the blood flow around the calcification in the brain was detected by single photon emission computed tomography, suggesting that the disorientation and gait disturbance were more likely due to a disturbed cerebral blood flow than to antiphospholipid syndrome. A plain X-ray and CT of the chest and abdomen showed neither any tumor or thymus enlargement. In addition, neither fibrosis of the lung nor any retention of fluid was present. A marked decrease in the \% VC (26.9\%) was seen, but the \% FEV1 (90.6\%) and DLCO (34.5 ml/min) were within the normal range. A decreased motility of the esophagus was shown by barium esophagography, but no distension was observed. No osteopenia or joint destruction was observed in the plain X-ray films. Electromyography (EMG) showed myopathic potentials with a waning phenomenon. A muscle biopsy of the quadriceps muscle showed diffuse and marked atrophy of the myofibers with a reduction in its diameter. Cell infiltration and muscle necrosis were absent. Tensilon test was not performed. Skin biopsy from a lower

From the Department of Clinical Immunology, Medical Institute of Bioregulation, Kyushu University, Beppu

Received for publication February 5, 1993; Accepted for publication July 13, 1993

Reprint requests should be addressed to Dr. Masayuki Yasuda, the Department of Clinical Immunology, Medical Institute of Bioregulation, Kyushu University, 4546 Tsurumihara, Beppu, Oita 874, Japan 


\section{YASUDA et al}

extremity with skin bleeding and pigmentation indicated leucocytoclastic vasculitis. Both Schirmer's test $(5 \mathrm{~mm}$ in the right eye and $2 \mathrm{~mm}$ in the left eye; normal $>10 \mathrm{~mm}$ ) and the Rose-Bengal test were positive. The Saxon test $(2.0 \mathrm{~g}$; normal $>3.0 \mathrm{~g}$ ) disclosed decreased salivation. Sialography was normal. A labial salivary gland biopsy remained unexamined.

Laboratory tests showed that the erythrocyte sedimentation rate (ESR) was markedly elevated to $109 \mathrm{~mm} / \mathrm{h}$, but the CRP was normal. The blood count showed a hemoglobin concentration of $12.3 \mathrm{~g} / \mathrm{dl}$, a mild peripheral leukocytopenia of $3.2 \times 10^{3} /$ $\mu \mathrm{l}$ and platelet count of $2.3 \times 10^{-5} / \mu \mathrm{l}$. Urinalysis was normal. Liver and kidney function tests including serum electrolytes showed normal values. Myogenic enzymes were all within normal ranges. Total protein was $8.2 \mathrm{~g} / \mathrm{dl}$ with increased gammaglobulin (40.8\%). IgG of 4,531 mg/dl (normal 1,125$1,738 \mathrm{mg} / \mathrm{dl}$ ), IgA of $433 \mathrm{mg} / \mathrm{dl}$ (normal $179-349 \mathrm{mg} / \mathrm{dl}$ ) and IgM of $704 \mathrm{mg} / \mathrm{dl}$ (normal $26-252 \mathrm{mg} / \mathrm{dl}$ ) were obtained. A slightly decreased hemolytic complement titer $(142 \mathrm{U} / \mathrm{ml}$; normal $158-255 \mathrm{U} / \mathrm{ml}), \mathrm{C} 3$ (73 mg/dl; normal $85-135 \mathrm{mg} / \mathrm{dl}$ ) and C4 (20 mg/dl; normal 33-65 mg/dl) was found. HLA was A24, A31, Bw61, Bw62, Cw3, DR2 and DR9. LE cells were positive and antinuclear antibody (ANA) was positive at $\times 2,560$ serum dilution (speckled pattern) and anti-DNA antibody was $10.7 \mathrm{IU} / \mathrm{ml}$ (normal; less than $10 \mathrm{IU} / \mathrm{ml}$ ). The antibody to extractable nuclear antigen (nENA) and RNaseresistant ENA (rENA) measured by passive hemagglutination were $\times 512,000$ and $\times 4,100$ serum dilution, respectively. Antiribonucleoprotein (RNP) antibody and anti-Sm antibody detected by Ouchterlony's double diffusion were $\times 128$ and $\times 4$ serum dilution, respectively. Antibody to SSA was positive at $\times 64$ serum dilution by Ouchterlony's double diffusion, but the anti-SSB was negative. Antibodies to Scl-70, centromere, Jo-1, thyroglobulin, microsome, smooth muscle and mitochondria were negative. Direct Coombs' test and cold agglutinin $(\times 512)$ were positive. Rheumatoid factor was positive at $121 \mathrm{IU} / \mathrm{ml}$ (normal; less than $18 \mathrm{IU} / \mathrm{ml}$ ). Antibody to AcR was positive (13 $\mathrm{nM} / \mathrm{l}$; normal <0.6) (6). Anti-cardiolipin antibody of IgG class was positive at 1.6 EIA unit (normal; less than $1.0 \mathrm{U}$ ) and platelet-associated $\operatorname{IgG}(\mathrm{PAIgG})$ was positive $\left(131.9 \mathrm{ng} / 10^{7}\right.$ of platelets; normal 9.0-25.0), but STS and lupus anticoagulant were negative. In addition, the antibody to human $\mathrm{T}$ lymphocytotropic virus I (HTLV-I) was negative.

The diagnosis of MCTD was made according to the diagnostic criteria proposed by Sharp and the Japan Ministry of Health

Table 1. Patients with the Association of MCTD and MG

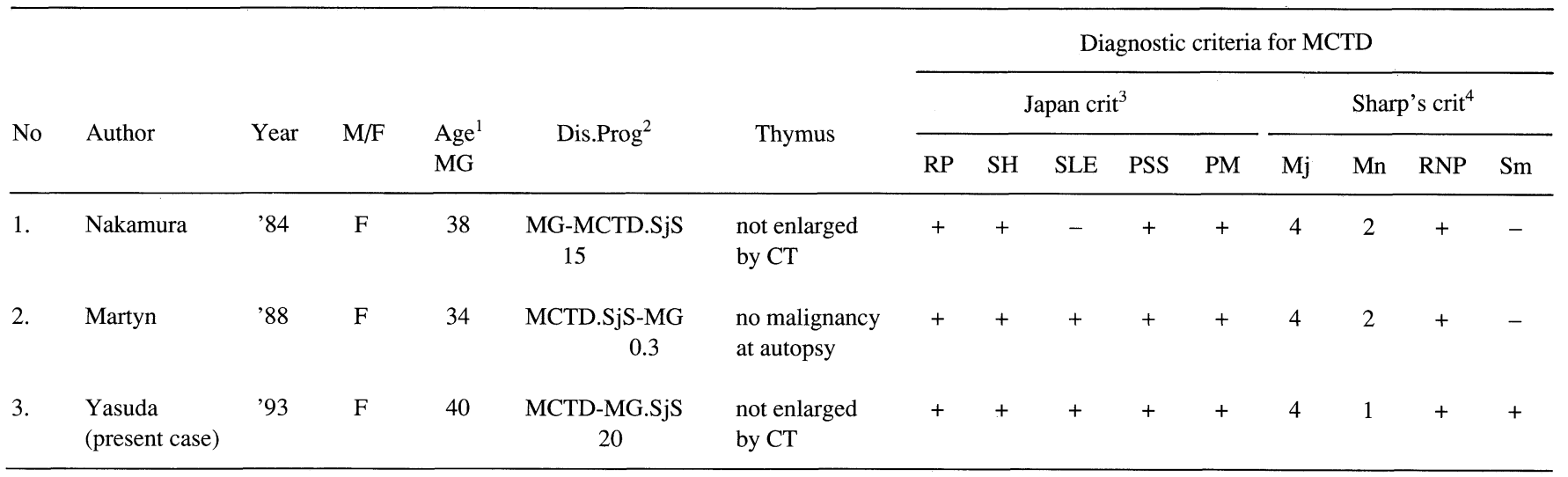

\begin{tabular}{|c|c|c|c|c|c|c|c|c|c|c|c|c|c|c|c|c|c|}
\hline \multicolumn{6}{|c|}{ Number of items fulfilled ${ }^{5}$} & \multicolumn{5}{|c|}{ Sjögren's syndrome $^{6}$} & \multicolumn{7}{|c|}{ Autoantibodies $^{7}$} \\
\hline & \multirow[t]{2}{*}{ SLE } & \multirow[t]{2}{*}{$\mathrm{PM} / \mathrm{DM}$} & \multirow{2}{*}{$\begin{array}{c}\text { PSS } \\
\mathrm{Mj} / \mathrm{Mn}\end{array}$} & \multicolumn{2}{|c|}{ RA } & \multicolumn{2}{|c|}{ Sicca } & \multirow[t]{2}{*}{ Sial } & \multirow[t]{2}{*}{ Biop } & \multirow{2}{*}{$\begin{array}{c}\text { Нyp } \\
\gamma \mathrm{G}\end{array}$} & \multirow[t]{2}{*}{ ANA } & \multirow[t]{2}{*}{ RF } & \multirow[t]{2}{*}{ AcR } & \multicolumn{2}{|c|}{ ENA } & \multicolumn{2}{|c|}{ DD } \\
\hline & & & & $\mathrm{Ar}$ & $\mathrm{Er}$ & Subj & Obj & & & & & & & $\mathrm{n}$ & $\mathrm{r}$ & RNP & $\mathrm{Sm}$ \\
\hline 1. & 2 & 4 & $-/ 2$ & nd & nd & - & + & + & + & + & $\times 1,280$ & nd & + & + & - & + & - \\
\hline 2. & 2 & 4 & $-/ 1$ & + & nd & + & + & nd & nd & nd & $\times 1,280$ & nd & nd & + & nd & + & nd \\
\hline
\end{tabular}

1) Age at onset of MG. 2) Initial disease, following disease and years between the two diseases. 3) Raynaud's phenomenon (RP), swollen hands and/or sclerodactylia (SH), mixed nature of SLE, PSS and PM/DM (SLE, PSS and PM). 4) The number of major (Mj) and minor (Mn) items which the patients had, and the presence (+) or the absence (-) of antibodies to RNP and Sm. 5) The number of diagnostic items that patients had. Diagnostic items proposed were by ARA in 1982 for SLE, by Bohan in 1975 for PM/DM; major (Mj) and minor (Mn) items for PSS by ARA in 1980. The presence or absence of arthritis (Ar) and bone erosion (Er) for RA. 6) Subjective symptoms of sicca (dry eye and dry mouth; Subj) and signs of sicca indicated by laboratory test (decreased lacrimation and salivation; Obj), apple tree pattern in sialography (Sial), cell infiltration in minor salivary gland biopsy (Biop) and the presence of hypergammaglobulinemia (Hyp $\gamma$ G). 7) Titer of antinuclear antibody (ANA) and staining pattern in parentheses, rheumatoid factor (RF), antibody to AcR (AcR), anti-ENA antibody to native (nENA) and RNase-resistant (rENA) by passive hemagglutination, and antibody to RNP and Sm by double diffusion (DD) are shown. nd: not defined by authors. 
and Welfare (Table 1) (3-5). The patients also fulfilled the diagnostic criteria for SLE (7). The waning phenomenon in EMG as well as the normal values in the myogenic enzymes and the positive anti-AcR antibody led to the diagnosis of MG (1). Sjögren's syndrome $(\mathrm{SjS})$ was diagnosed by the presence of sicca complex (8). We administered $30 \mathrm{mg} /$ day of prednisolone. Ptosis of the eyelids and muscle weakness in the lower extremities disappeared gradually. The waning phenomenon in EMG eventually disappeared. The degree of disorientation also improved. Normalization of the WBC count $(5,600 / \mu \mathrm{l})$ and ESR $(20 \mathrm{~mm} / \mathrm{h})$, and a decrease in hypergammaglobulinemia, RF $(69 \mathrm{IU} / \mathrm{ml})$ and antibody titers to nENA $(\times 81,920), \mathrm{RNP}(\times 10)$ and $\operatorname{Sm}(\times 1)$ were also obtained. Furthermore, the antibodies to AcR, DNA and cardiolipin became negative. Following 3 months of corticosteroid administration, the patient was eventually discharged from our hospital and received $15 \mathrm{mg}$ /day of prednisolone.

\section{Discussion}

The present case demonstrated the coexistence of MCTD and MG. Although MCTD was originally proposed 20 years ago with the first report by Sharp et al in 1972 (3), the reported association of MG and MCTD has been unexpectedly rare; and up to now only two such reports have been published (Table 1) $(9,10)$. Since all 3 MCTD cases, including the 2 previously reported cases and the present case, have fulfilled the diagnostic criteria for either PM/DM or SLE, we searched for reports concerning the association of MG and PSS, PM/DM, or SLE consisting of the mixed nature of MCTD (3-5). Since all 3 MCTD patients with MG had $\mathrm{SjS}$ and the rate of $\mathrm{SjS}$ coexisting in MCTD patients was markedly high in our study, we also looked for reports concerning the association of $\mathrm{SjS}$ and MG (11). The number of patients showing the coexistence of MG

Table 2. Patients with the Association of SjS and MG

\begin{tabular}{|c|c|c|c|c|c|c|c|c|c|c|c|}
\hline \multirow[t]{2}{*}{ No } & \multirow[t]{2}{*}{ Author } & \multirow[t]{2}{*}{ Year } & \multirow[t]{2}{*}{$\mathrm{M} / \mathrm{F}$} & \multirow{2}{*}{$\begin{array}{l}\text { Age } \\
\text { MG }\end{array}$} & \multirow[t]{2}{*}{ Dis.Prog } & \multirow[t]{2}{*}{ Thymus } & \multicolumn{2}{|c|}{ Sicca } & \multirow[t]{2}{*}{ Sialo } & \multirow{2}{*}{$\begin{array}{l}\text { Saliv } \\
\text { biopsy }\end{array}$} & \multirow{2}{*}{$\begin{array}{l}\text { Hyper } \\
\gamma G\end{array}$} \\
\hline & & & & & & & Subj & Obj & & & \\
\hline 1. & Downes & '66 & $\mathrm{F}$ & 17 & $\begin{array}{c}\text { MG-TX-SjS } \\
21\end{array}$ & no tumor & + & + & nd & nd & + \\
\hline 2. & Whaley & '73 & $\mathrm{F}$ & 52 & $\begin{array}{c}\text { RA-MG-SjS } \\
2\end{array}$ & $\begin{array}{l}\text { normal on } \\
\text { X-ray film }\end{array}$ & + & + & nd & nd & nd \\
\hline 3. & Whaley & '73 & $\mathrm{F}$ & 25 & $\begin{array}{c}\text { MG-TR-RA-SjS } \\
14 \quad 2\end{array}$ & nd & + & + & nd & nd & nd \\
\hline 4. & Whaley & '73 & $\mathrm{F}$ & 63 & $\begin{array}{l}\text { MG-SjS-RA } \\
12\end{array}$ & nd & + & + & + & nd & nd \\
\hline 5. & Arimori & $' 73$ & M & 40 & $\begin{array}{c}\text { MG-SjS } \\
11\end{array}$ & $\begin{array}{l}\text { enlarged on } \\
\text { X-ray film }\end{array}$ & + & + & + & + & + \\
\hline 6. & Saito & 75 & M & 48 & $\begin{array}{l}\text { SjS-MG-TX } \\
5\end{array}$ & benign tumor & + & + & + & nd & - \\
\hline 7. & Yoshino & '82 & $\mathrm{F}$ & 20 & $\begin{array}{l}\text { MG-TR-RA.SjS } \\
5\end{array}$ & $\begin{array}{l}\text { enlarged on } \\
\text { X-ray film }\end{array}$ & - & + & nd & nd & + \\
\hline 8. & van Offel & '87 & $\mathrm{F}$ & 68 & $\begin{array}{c}\text { RA-DPC-MG.SjS } \\
0.3\end{array}$ & nd & nd & + & + & + & nd \\
\hline 9. & Mizuno & '88 & $\mathrm{F}$ & 60 & $\begin{array}{l}\text { RA-SjS-MG-TX } \\
\quad 13\end{array}$ & hyperplasia & + & + & nd & nd & + \\
\hline 10. & Siden & '90 & $\mathrm{F}$ & 40 & $\begin{array}{l}\text { MG-SjS-TX } \\
1\end{array}$ & hyperplasia & - & - & nd & + & nd \\
\hline
\end{tabular}

Diagnostic items fulfilled

\begin{tabular}{cccccclll} 
& SLE & PM/DM & PSS & \multicolumn{2}{c}{ RA } & & \\
No. & & & & Ar & Er & AcR & ANA & RF \\
\hline 1. & 2 & 0 & 0 & + & - & nd & $\times 200(\mathrm{sp})$ & + \\
2. & 1 & 0 & 0 & + & + & nd & $\times 100$ (h.sp) & + \\
3. & 1 & 0 & 0 & + & + & nd & $\times 4,000($ h.sp $)$ & + \\
4. & 1 & 0 & 0 & + & + & nd & $\times 256(\mathrm{~h})$ & + \\
5. & 0 & 0 & 0 & - & - & nd & - & + \\
6. & 0 & 0 & 0 & - & - & nd & - & - \\
7. & 2 & 0 & 0 & + & + & + & $\times 320($ h.sp $)$ & + \\
8. & 3 & 0 & 0 & + & nd & + & $\times 160$ & + \\
9. & 0 & 0 & 0 & + & + & + & - & + \\
10. & 1 & 0 & 0 & nd & nd & + & - & + \\
\hline
\end{tabular}

Case 2 had hypothyroidism while case 9 had hyperthyroidism. nd: not defined by authors. 
and CTD totaled 3 for PSS, about 80 for PM/DM, about 50 for SLE and 10 for SjS (Table 2) (12-23). However, none of them fulfilled the diagnostic criteria for MCTD and it is thus concluded that the association of MCTD and MG is rare. It has been reported that the most common CTD associated with MG is rheumatoid arthritis (RA), but the pathogenesis for the greater part of the patients was ascribed to the administered Dpenicillamine $(1,2,6,24)$. D-penicillamine has been demonstrated to bring about an autoimmune phenomenon including MG $(6,24)$. However, none of the 3 MCTD patients was administered D-PC.

Consequently, we could not find any obvious pathological basis for the association of MG and MCTD. However, we would like to discuss the importance of the association of $\mathrm{SjS}$, since the characteristics of our MCTD patient, including the demonstration of various autoantibodies and sicca complex, are the same as those for $\mathrm{SjS}$. The association of SjS with MCTD has ranged from $7 \%$ to $48 \%(3,25)$, from $40 \%$ to $98 \%$ in SLE (26-29), and $17 \%$ to $88 \%$ in PSS (30-33) in recent reports. We also showed that positive sialectasis was found in $82 \%$ of the patients with MCTD (11). Lindahl et al showed a prevalence as high as $73 \%(8 / 11)$ of positive lymphocytic infiltration in labial salivary gland biopsies of the patients with MG (34). These findings suggest that the previous authors did not pay much attention to the presence of SjS because of a lack of symptoms even in the presence of salivary gland damage. It is thus reasonable to speculate that the unnoticed association of $\mathrm{SjS}$ in previously reported cases should have been much more frequent than what was actually described.

Patients with SjS are reported to have a decrease in suppressor-inducer T-cells in the peripheral blood and an increase in immunoglobulin secreting B-cells in the saliva $(35,36)$, which were responsible for the polyclonal activation of B-cells and the presence of polyspecific antibodies to self organs. The affinity of antibodies produced by the polyclonal activation of B-cells is reported to be low and polyspecific and MG patients associated with malignancies are generally responsive to drug therapy such as corticosteroid administration $(1,35,36)$. In this sense, it should be noted that the administration of prednisolone in our patient was markedly effective. In addition, an immediate decrease of autoantibody production including anti-AcR antibody following corticosteroid administration may suggest the participation of the polyclonal activation of B-cells. Such abnormalities might have resulted in the generation of autoantibodies to the AcR, phospholipid, and blood cells. None of the 3 MCTD patients showed either any obvious thymus enlargement or tumors, but the correlations between CTDassociated $\mathrm{MG}$ and thymus abnormalities have been previously discussed by many authors $(1,9,13-16,19,20)$. Based on the above findings, we thus speculate that thymus abnormalities may have played a role in the present case, too.

We therefore conclude that one of the pathological bases for the coexistence of MG and MCTD is likely immune system disorders, which might manifest themselves as $\mathrm{SjS}$ with exocrine gland damage and polyclonal B-cell activation.

\section{References}

1) Simpson JA. Myasthenia gravis: A new hypothesis. Scot Med J 5: 419, 1960.

2) Pirskanen R. Genetic aspects in myasthenia gravis. A family study of 264 Finnish patients. Acta Neurol Scand 56: 365, 1977.

3) Sharp GC, Irvin WS, Tan EM, et al. Mixed connective tissue disease - an apparently distinct rheumatic disease syndrome associated with a specific antibody to an extractable nuclear antigen (ENA). Am J Med 52: 148, 1972.

4) Sharp GC. Diagnostic criteria for classification of MCTD. in: Mixed Connective Tissue Disease and Anti-nuclear Antibodies. Kasukawa R, Sharp G, Eds. Elsevier Science Publishers B.V., Amsterdam, 1987, p.23.

5) Kasukawa R, Tojo T, Miyawaki S, et al. Preliminary diagnostic criteria for classification of mixed connective tissue disease. in: Mixed Connective Tissue Disease and Anti-nuclear Antibodies. Kasukawa R, Sharp G, Eds. Elsevier Science Publishers B.V., Amsterdam, 1987, p. 41.

6) Morel E, Feuillet-Fieux MN, Garabedian BV-D, et al. Autoantibodies in D-penicillamine-induced myasthenia gravis: a comparison with idiopathic myasthenia and rheumatoid arthritis. Clin Immunol Immunopathol 58: 318, 1991.

7) Tan EM, Cohen AS, Fries JF, et al. The 1982 revised criteria for the classification of systemic lupus erythematosus (SLE). Arthritis Rheum 25: 1271, 1982.

8) Talal N. Sjögren's syndrome and connective tissue diseases associated with other immunologic disorders. in: Arthritis and Allied Condition. A Textbook of Rheumatology. Eleventh Ed, McCarty DJ, Ed. Lea \& Febiger, Philadelphia, 1989. p. 1197.

9) Nakamura Y, Takahashi M, Nishikawa $Y$, et al. Coexistence of mixed connective tissue disease and myasthenia gravis. Saishinigaku 42: 2684, 1987 (in Japanese).

10) Martyn JB, Wong MJ, Huang SHK: Pulmonary and neuromuscular complications of mixed connective tissue disease: a report and review of the literature. J Rheumatol 15: 703, 1988.

11) Ohtsuka E, Nonaka $S$, Yasuda M, et al. Sjögren's syndrome and mixed connective tissue disease. Clin Exp Rheumatol 10: 339, 1992.

12) Mitchell GW, Lichtenfeld PJ, McDonald CJ. Myasthenia gravis and scleroderma. An unusual combination of diseases. JAMA 233: 531, 1975.

13) Namba T, Brunner NB, Grob D. Association of myasthenia gravis with pemphigus vulgaris, candida albicans infection, polymyositis and myocarditis. J Neurol Sci 20: 231, 1973.

14) Behan WMH, Behan PO, Doyle D. Association of myasthenia gravis and polymyositis with neoplasia, infection and autoimmune disorders. Acta Neuropathol 57: 221, 1982.

15) Ciaccio M, Parodi A, Rebora A. Myasthenia gravis and lupus erythematosus. Int J Dermatol 28: 317, 1989.

16) Downes JM, Greenwood BM, Wray SH. Auto-immune aspects of myasthenia gravis. Q J Med 137: 85, 1966.

17) Whaley K, Webb J, McAvoy BA, et al. Sjögren's syndrome. 2. Clinical associations and immunological phenomena. Q J Med 167: 513, 1973.

18) Arimori $S$, Tanaka $Y$, Tada $S$, et al. Thymic hypertrophy with manifestation of Sjögren's syndrome after remissionof myasthenia. Nippon Rinsho 31: 393, 1973 (in Japanese).

19) Saito M, Hirayama K, Narabayashi H. Myasthenia with the Sjögren's syndrome and thymoma - clinical evaluation of myasthenic syndrome. Rinsho Shinkeigaku 15: 811, 1975 (in Japanese).

20) Yoshino S, Morishige T, Fujimori J, et al. A case of myasthenia associated with rheumatoid arthritis and Sjögren's syndrome. Ryumachi 22: 315, 1982 (in Japanese).

21) van Offel JF, Franckx LM, De Clerck LS, et al. Differential diagnosis in a patient with secondary Sjögren's syndrome and neuromuscular complication. Brit J Rheumatol 26: 470, 1987.

22) Mizuno $T$, Hashimoto $T$, Hibino $N$, et al. A case of myasthenia gravis associated with rheumatoid arthritis, Sjögren's syndrome, hypergammaglobulinemia and hyperthyroidism. Nippon Kyobu Geka Gakkai Zasshi 36: 1191, 1988 (in Japanese). 


\section{MCTD Presenting Myasthenia Gravis}

23) Siden A, Lindahl SA. Signs of Sjögren's syndrome in a patient with myasthenia gravis. Acta Neurol Scand 81: 179, 1990.

24) Cooperative Systematic Studies of Rheumatic Disease Group. Toxicity of long term low dose D-penicillamine therapy in rheumatoid arthritis. J Rheumatol 14: 67, 1987.

25) Alarcon-Segovia D. Symptomatic Sjögren's syndrome in mixed connective tissue disease. J Rheumatol 3: 191, 1976.

26) Skopouli F, Siouna-Fatourou H, Dimou GS, et al. Histologic lesion in labial salivary glands of patients with systemic lupus erythematosus. Oral Surg Oral Med Pathol 72: 208, 1991.

27) Alarcon-Segovia D, Ibanez G, Velazauez-Forero F, et al. Sjögren's syndrome in systemic lupus erythematosus. Clinical and subclinical manifestations. Ann Intern Med 81: 577, 1974.

28) Moutsopoulos HM, Klippel JH, Pavlidis N, et al. Correlative histologic and serologic findings of sicca syndrome in patients with systemic lupus erythematosus. Arthritis Rheum 23: 36, 1980.

29) Coll J, Rives A, Grino MC, et al. Prevalence of Sjögren's syndrome in autoimmune diseases. Ann Rheum Dis 46: 286, 1987.

30) Drosos AA, Andonopoulos AP, Costopoulos JS, et al. Sjögren's syn- drome in progressive systemic sclerosis. J Rheumatol 15: 965, 1988.

31) Cipoletti JF, Buckingham RB, Barnes EL, et al. Sjögren's syndrome in progressive systemic sclerosis. Ann Intern Med 87: 535, 1977.

32) Osial Jr TA, Whiteside TL, Buckingham RB, et al. Clinical and serologic study of Sjögren's syndrome in patients with progressive systemic sclerosis. Arthritis Rheum 26: 500, 1983.

33) Alarcon-Segovia D, Ibanez G, Hernandez-Ortiz J, et al. Sjögren's syndrome in progressive systemic sclerosis (scleroderma). Am J Med 57: 78, 1974.

34) Lindahl G, Lefvert A-K, Hedfors E. Periductal lymphocytic infiltrates in salivary glands in myasthenia gravis patients lacking Sjögren's syndrome. Clin Exp Immunol 66: 95, 1986.

35) Sato K, Miyasaka N, Yamaoka K, et al. Quantitative defect of CD4+2H4+ cells in systemic lupus erythematosus and Sjögren's syndrome. Arthritis Rheum 30: 1407, 1987.

36) Yamaoka K, Miyasaka N, Yamamoto K. Possible involvement of EpsteinBarr virus in polyclonal B cell activation in Sjögren's syndrome. Arthritis Rheum 31: 1014, 1988. 